\title{
Sustaining tourism in South African game farms: the benefits of ownership of restituted land by African communities
}

\author{
M. P. Sebola \\ Department of Public Administration, \\ University of Limpopo, South Africa
}

\begin{abstract}
The purpose of this paper is to argue that land restituted for ownership by black communities in South Africa is unable to attract tourists compared to previous private ownership. The South African government introduced land restitution through their land reform policy in order to redistribute land equally to South African communities. Equally, the process as viewed from the critics' perspective; the land reform process portrays an image of a country that is taking over land from ownership of white minority class to ownership by Africans. Ownership of land in the country was racially skewed with $87 \%$ of productive land owned by the white people in the country with Africans congested to $13 \%$ of infertile and unproductive land. The Land Restitution Act of 1994 was passed to ensure that Africans are beneficiaries of new land allocation through the willing buyer willing seller principle. The ownership of land by Africans (Blacks) is viewed to a particular extent as being responsible for low economic output from game farms as compared to ownership by previous owners. This paper is conceptual and intends to investigate and establish the cause and reasons of low output of game farms through tourism. The purpose of this paper is to propose a useful model that South Africa could adopt for the benefit of new owners who are exclusively black. This paper therefore concludes that a new approach by the government aimed at promoting economic activities of game farmers (black game beneficiaries) is possible through continuous monitoring, mentoring, support and enforcement of good managerial practices of the Communal Property Associations.
\end{abstract}

Keywords: land reform, land restitution, game farm, tourism, communal property association. 


\section{Introduction}

The South African government introduced a willing-buyer willing-seller principle to attract white farmers that voluntarily wanted to sell their farms to the government at current market related value. That was a peaceful manner of resolving the land inequality problems in which bought land is returned to the black communities previously removed through past racial legislation. Some farmers sold to the government their game farms as per requirements of the willing buyer willing seller principle. Such farms were given over to the new management of black communities through Communal Property Associations as established by those communities in terms of the requirements of the law. The ownership by new beneficiaries has been to a particular extent responsible for low economic output from such farms as compared to ownership by previous owners. This is a conceptual paper based on literature analysis and it raises the following question: Are there quantifiable benefits generated from restituted lands in South Africa to benefit the government and the local people? In addressing the question posed, this paper will keep its relevance to the following aspects; the land reform process in South Africa, the political Significance of land restitution in South Africa, game farms and tourism in South Africa, Communal Property Associations and Game farm management models, Benefits from restituted farms and possible options for solution.

\section{South Africa's land reform and restitution}

South Africa's land reform processes follow two processes: The land restitution by which Africans were dispossessed of their land in 1913 and the redistribution of land to deal with hunger and land ownership inequality (African National Congress [1]). The Land Restitution Act of 1994 in South Africa (which is a focus of this paper) gives the black communities the opportunity to claim back their land lost because of the implementation of the Native Land Act of 1913 by the previous apartheid regime which caused skewed patterns of land ownership in the country characterising the South African land ownership environment even today. The Native Land Act of 1913 prohibited Africans (Blacks) from owning land outside the rural reserves which only constituted $13 \%$ of the South African land (Bradstock [2], Velente [3], South African Institute of Race Relations [4]). It has been argued that the said 13\% was indeed given to Africans based on the geological survey done and confirmed that the portions are indeed infertile and unproductive. The African people then lacked that knowledge of science. And therefore were removed and compensated with areas where no reasonable agricultural or economic activities are likely to take place. The selected productive and fertile land $(87 \%)$ was therefore reserved for the white minority class so that they can practice productive agriculture and sound economic activities for the country. That is a move which by design aimed to portray Africans as less economically productive citizens against their white counterparts. By design such system meant to subject African people to being job seekers to white commercial farmers and was not to engage in any sound 
economic activities except for those that will subject their produce to the white commercial farmers. The worst part of the Native Land Act of 1913 was that even though an African can afford a property but was not allowed to buy a farm from a white man and therefore could not own a property within the $87 \%$ demarcated area allocated to white ownership.

For purposes of nation building, reconciliation and peace the African National Congress (ANC) introduced the Land Restitution Act of 1994 as a peaceful means to achieve land redistribution by striving for equity in property ownership. The willing buyer willing seller principle was a peaceful gesture than the violence and discriminatory manner by which the white minority government took land from the Africans in the past. This principle yielded some goods results in the sense that some farmers voluntarily sold their farms to the government as required, but on the same note most white minority farmers in the country did not respond positively to the gesture as suggested and therefore are said to be delaying the objectives of the Land Restitution Act that a particular percentage of farm ownership by Africans should have been achieved at some stage. According to Metelerkamp [5] and South African History Online [6] the government intended to achieve a 30\% land allocation to Africans by 2014, an objective which thus far sound impossible to achieve since it risks a budget shortfall of 72 billion rands (Paul [7]). On the other hand farms that are already owned by African farmers are denoted negative and are said to have been responsible for economic loss in agricultural production of the country. Tourists' intake in game farms is argued to be going down with unsustainable features of profit losses and managerial problems in which restituted farms are either occupied by few families or are completely disserted. Hall [8] argues that most restituted farms are either underutilised or are used for less productive activities such as grazing land. Such activities are subjecting the efforts of the South African land reform into nothing other than an economic loss of agricultural commodities of the land.

\section{The political significance of land restitution in South Africa}

The issue of land restitution in South Africa is mainly viewed from its political significance other than economics of land redistribution. Brandon [9] showed that from the period 1994-2013 the government of South Africa has spent approximately R25.72 billion. It is known, however, that land was always a central political denominator for African struggle against the white settlers (Kariuki [10]). Land issue in South Africa and other parts of Africa as a whole is still a highly political matter in the country because of the manner by which it was taken from the local people. The politically conscious manner by which the South African government is handling land issue is criticised by both the external communities and the local as a manner that could results in political turmoil in future. Unlike the Zimbabwean arrangements of the Lancaster House Agreement (Lancaster House Agreement [11], Africa All Party Parliamentary Group [12]), in which the British government promised the Zimbabwean government compensation on behalf of its citizens in Zimbabwe, the South 
African government on its own promised to take care of the costs of redress for its own people. This was mainly a move to fulfill reconciliation and on the other hand repossessing the land from the white minority in a peaceful and human manner as possible.

Fourie and Schoeman [13] are of the opinion that land restitution of South Africa which cannot be viewed outside the political environment should be seen as a vehicle for socio-economic empowerment for black people than mere settling of claims. The settlement of these claims is however not viewed outside the perspective of political revenge by the previous beneficiaries of the system who accused the present government for implementing apartheid in reverse by taking land from selected race of whites' people. The adopted approach by the South African government of willing buyer willing seller principle is criticised for its humanitarian approach which according to Sangonet [14] is giving former land owners an option of either not selling or selling the farms to the government at exorbitant prices. The South African government is however trying its best to find a reasonable political solution which in turn the African citizen view as being too soft against people who took the land violently from its owners. To a particular extent the South Africans feels that the Zimbabwean- Mugabe route is better in situation like this where the approach is delaying the government to achieve its set objectives. On other hand as England [15] attests is that the land reform process in South Africa is very slow- but those that were given land also are struggling with lack of resources to manage their claimed farms successfully.

It can be argued that the South African government approach to land restitution is more informed by politics of reconciliation than politics of revenge. In trying to resolve land claim as a political problem in South Africa the government tries by all means to satisfy the needs and interests of both the white minority farmers and the African majority who claims that the occupied land by famers rightfully belongs to them. This is shown by the government willingness to pay in financial terms the claiming society than giving them a farm (White [16]) or providing an alternative farm to the claimants other than removing a farmer (Stickler [17]). This means that a political settlement would have been achieved other than removing a farmer from the land he is tilling and producing for the country. It is not clearly known however whether the government would have sustainable resources to buy farms for both the whites and Africans demanding compensation either in the form of money or land or an alternative land. It may seem from the practical South African experience that the government is not coping with either of the available options its sets for the land restitution process. Weideman [18] and Lahiff [19] argue that the land reform of South Africa has completely failed to achieve set objectives by long margins which include inability to achieve targeted percentage before 2014 and the dominance of agriculture by similar commercial farmers( white minority group). It is therefore possible to conclude that the political solution used by the current government in solving land issues is not progressive. The likelihood is that solving land issues by balancing the interests of white farmers and the anticipated aggrieved African farmers on similar scale is derailing the progress of land reform and rendering the countries land reform policies ineffective. 
Whether the land reform is meant to achieve a political objective or otherwise the economic considerations are equally also important. Of significance in land acquisition is its ability to sustain the economics of its agriculture. Restituted game farms in South Africa are heavily affected by land claims controversies and therefore threatening their economic potential through tourism that used to sustain them.

\section{Game farms and tourism in South Africa}

Van der Merwe and Saayman [20] define a game farm as an adequately fenced land, with a variety of game species that can be used for hunting, photographic opportunities, environmental education, meat production, life game sales and which provides infrastructure and superstructures for eco tourists. Game farms are an important part of what is called rural tourism (Viljoen and Tlabela [21]) which unlike other conventional forms of tourism which are not pro-poor in approach. Game farms in South Africa are major contributors to tourism related activities through both hunting and accommodation provision. Game hunting in South Africa plays a significant contribution into the local economy (Langholz and Kerley [22], Saayman et al. [23]) through seasonal employment of game guides and buying of local products by tourists.

The game industry in South Africa rests on three pillars (hunting, game trade and eco-tourism) which are highly driven by trophy and biltong hunting (Cloete et al. [24]). The economic contributions statistics of game farms are that in 2005 trophy hunting generated R417 million, biltong hunting 2.3 billion while life game auctions contributed R93.5 million to game ranchers therefore making game farming in South Africa the most attractive tourism economic related activity. Child et al. [25] indicated that trophy hunting alone generate billions of dollars in South African revenue. And such dollars are significant for the South African economy in a diverse manner.

South Africa because of its rich biodiversity is a preferred tourist destination for nature and eco-tourists (Sebola [26]). According to Carruthers [27] South Africa is the third most bio diverse nation in the globe. With the exclusion of national parks and other government managed tourists attractions in the country, private game farms are said to be very effective in attracting international tourists because they are meant to achieve a maximum profit for their owners and benefit the local communities in a manner that is either direct or indirect. Most private game farms have high class accommodation facilities and effective management structures compared to government managed attractions which do not exists for purposes of profit.

South Africa is reportedly having closer to 9000 private game farms registered and about 6000 which are unregistered or in the process of registration (Cousins et al. [28]; Child et al. [25]) and its economic contributions to tourism is increasing at a larger scale while normal agricultural farming is showing a significant decline in revenue. Smith and Wilson [29] have noted that South Africa have shifted from pastoralism to game farming as early as in the 1980s. This move shows that game farming has always been considered significant for 
long in South Africa. It is however the same move which has resulted in land dispossessions for local Africans that resulted in land ownership disparity in the country. Most literature on the practice of conservation in South Africa argues that the government forcibly removed the locals from their areas in order to make space for nature conservation reserves without providing alternative means of survival for the dispossessed communities. That has often raised serious political questions like how do you entertain the tourists at the expense of landless South Africans who are barred from the vicinity of their own land? Other than the politics of land dispossessions, game farming is arguably a rising mode of tourism related activity in South Africa. And this rising tourism mode is currently highly affected by the land claims processes which to a particular extent land offered under the restitution legislation are unable to attract tourists because of the lowered standards under the management of Communal Property Associations which shows little interest in further development of the already existing infrastructure.

\section{Game farming and land claims}

Ironically in South Africa the land claimants targeted only economically active conservation areas, game farms and agricultural lands. This kind of approach in land claims was criticised by minority farm owners who accused the claimants of only wishing to take land that is already economically developed and leaving the less developed farms. The peaceful approach of land claim in South Africa is often likened to the Zimbabwean situation in which the war veterans only attacked and repossessed violently only farms that were well developed with good technologies and machineries. That is the behaviour which thus far has risked the economic stability of Zimbabwe which is a direction the South African people are avoiding at all costs. South Africa is very conscious in dealing with issues that will destabilise the tourism potential of a country. It is acknowledged that historically the country managed to move tourism contribution to the economy from $4 \%$ to closer to $10 \%$ in post-apartheid South Africa. Manji [30] however argues that the whole behaviour of violent takeover of lands by modern societies has all to do with the realisation that the civil handling of land issue in Africa does not want to see its conclusion therefore violent take over by the dispossessed becomes legitimate. In South Africa very few of the land claimed seems to be sustainably used by the new beneficiaries. Their management are often queried and criticised as contributing to low economic output in comparison to economic performance of the previous owners. One of the few successful cases of land claims and benefits in South Africa is of the Makuleke Community at the Kruger National Park and it differs from other cases in the country (Spenceley [31]) in the sense that the Makuleke land claims achieved wider media coverage and sympathy from many institutions. Other than that the Makuleke Community made a land claim against a national park other than a simple game farm or a non- economic provincial nature reserve in which the management never included the local communities. The Kruger National Park established a Social ecology unit to work in 
collaboration with the same communities in the 1980s (Spenceley [32]) almost fourteen years before the formalisation of the land claims in the country. This may therefore imply that the Makuleke Community have indeed benefitted from the benefits of conservation at the Kruger National Park long before their successful land claim against the Kruger National Park management. This can therefore be treated as an isolated case of land restitution.

\section{Communal Property Associations and game farm management models}

Most land claimant's beneficiaries in South Africa prefer the model of managing claimed farms through the Communal Property Association (CPA) model than the Community Trusts (CT). The CPA model is preferred because it is democratic in the sense that it has an established constitution in which the term of office for office bearers may have a prescribed term other than the Community Trusts that will put ownership of land under the trust of a chief. Chieftainship is not significantly trusted since Chiefs often uses the communities' funds for own benefit than the people and that Chiefs are traditionally not supposed to account to their subjects.

There are commonly three partnership models that are used in farm management practice to benefit the dispossessed (Aliber and Maluleke [33]) and at the same time increasing the possibility of the economic productivity of the distributed land. Those are farm worker share equity schemes (in which land redistribution applicants are awarded grants to purchase equity in a going concern and become part of the farm management); strategic partnerships (in which an operating company is created and the community owns half or more of the share and the strategic partnership balance in which the agricultural land operates through a lease agreement wherein the present owner is expected to transfer skills and employ beneficiary communities); and, the out-grower schemes (in which the small-scale farmers are linked to an agro-processor). The adoptions of any of these models are not a problem per se, but the unknown nature of these models by the dispossessed beneficiaries could poses economic challenges that the ruling party does not seek to confront. However at smallscales, these models have not only been applied to improve the efficiency of farm land for the dispossessed in South Africa, but have also been attempted in communal nature reserves without significant successes (Sebola [34]). To a larger extent most South African beneficiary communities spent most of their time arguing with their Communal Property Associations (CPA) about which model to adopt and often failing to delegate their representatives to enter into such unknown contracts on their behalf. As a result, acquired land properties end up being unprofitably used. To those beneficiary communities in which the CPA succeeded in entering into contracts with partners to improve the effectiveness of the claimed agricultural land, members of the beneficiary communities have continued to hold negligible knowledge and skills about the activities taking place in their farms. As such the tourism potential of such game farms becomes 
impossible to operate effectively. Barry [35] also noted that the other causes of conflict in claimed land come to the fore when other beneficiaries considers themselves to be rightful beneficiaries than others. Those ultimately limit the farms ability to sustain its usability to benefit the targeted beneficiaries.

\section{Benefits from restituted game farms}

The benefit of the South African communities from the land restitution programme is very complex. Up to so far they have been many challenges of disputes among beneficiaries of land claimed. South African Institute of Race Relations [4] noted that the fact that the claimed land is owned by the community than by individual community members is a flaw on its own. It could be argued that a farm can only function effectively if it is owned by an individual than a group. The farm and its property need an individual who can accept a full responsibility of running costs of the farm business. Thus far in communal lands of South Africa meant for either game farming or agricultural farming of any type the communities running the farms are failing to take financial responsibilities of maintaining the farm claimed. That ultimately led to members leaving the given land with dysfunctional facilities which will affect its economic productivity. Dikganga and Muchapondwa [36] argue that a land reform programme is measured by its success in bringing about wealth, consumption and income to the beneficiaries. In the South African situation such a claim might be difficult to make considering the fact that more beneficiaries of such land claims deserted the claimed lands which automatically denounces their membership of the communal land. While land is a rare commodity and a requirement for economic benefits, but restituted game farms in South Africa are not able to make an expected economic benefits to the targeted communities as expected.

The end results of game farm management through CPA's are that only the minority groups within the beneficiary communities knows what is going on in claimed farms. Bennett [37] mentioned that CPA's are supposed to be accountable institutions in local resources management. To a particular extent the CPA's existence as a structure of local resource management often are in conflict with the tribal institutions under which such land claims have been made. That ultimately made the benefits from claimed farm difficult to measure and attests. Chairpersons of CPA's often claim to report the farm activities directly to the Director-General of Land Affairs than to the Community and the Chiefs. The accountability part of the CPA's therefore becomes questionable. Not only is this a problem to the communities concerned, but it is also a problem for the government that has authorised or bought on behalf of the community an economically active game farms which have not lost their productive value. Most farms acquired through the land restitution are dysfunctional and their one time attractive facilities are in a state of dilapidation. There is low tourists intake and therefore their role as tourism destinations are not sustainable anymore. Although communal lands under the CPA's are meant for agricultural purposes 
than residential (McCusker [38]), there has been a lot of conflict among community members whom others feel they should be for residential settlement while others are arguing for grazing land usage only.

\section{Are there available options?}

The options between the political and economic route is not easy to take. The land restitution process should move from its political perspective towards economic considerations. Governments of colonial history such as South Africa find it difficult to consider economic issues against political issues. More often than not political considerations supersede the economic considerations. The reality is that people do not eat political talks than economic difficulties facing them on daily basis. It is understandable that land ownership disparity is a serious political concern of governments' administration, but of significance is that economic realities should not be discounted in the process. It is a fact that governments have always disregarded the interests of the local communities against the needs of the tourists, therefore meeting their economic needs and caring less about the satisfaction level of the local communities. Rolston [39] has argued that there should be a balance between tourism interests and those of the community. In this instance the South African government need to balance the political needs of the people on land ownership as against the economic needs of the country to support the same people. Thus far there is a great imbalance of land distribution issues. However not enough, but literature on game farming show that game ranching contributed a lot in the tourism economy through accommodations (lodges), hunting and game auctions (Cloete et al. [24]) in the previous years. The economically deteriorating status of some restituted game farms are likely to take the tourism potential of the country down and results in major economic loss for a country. Options are indeed difficult to either retain the unequal ownership of land in the country or to compromise the economic potential of restituted game farms. A recommended solution in this case is that an approach be reconsidered in which restituted game farms can be allocated responsible entrepreneurs who will account to the government on their activities. The government should on regular basis audit the benefits of the restituted farms to the intended beneficiaries in which remedial actions should be taken if they are not measurable.

\section{Conclusion}

This paper argues that game farms obtained by communities through land restitution in the country are not beneficial to the intended communities. Neither are they beneficial to the South African government in economic terms. Game ranching or rather game farming has a good record of contributing to the tourism economy in many forms which are either direct or indirect. Directly the contributions are through accommodations game hunting and game auctions. Indirect contributions are through employment, buying of local goods by tourists and local filling stations. Of significance also is the contributions top 
government by means of taxations. Information gathered from literature analysis on the subject of enquiry shows that indeed the game farms obtained through restitution requires a new approach by the South African government in order to benefit either government or the intended beneficiaries or both.

\section{References}

[1] African National Congress. Policy on the Restitution of Land Right. http://www.anc.org.za/show.php?id+228.

[2] Bradstock, A., Changing Livelihoods and Land Reform: Evidence from the Northern Cape Province of South Africa. World Development, 33 (11), 1979-1991, 2005.

[3] Velente, C., The food (In) Security Impact of Land Redistribution in South Africa: Micro econometric Evidence. World Development, 37 (9), 1540-1553, 2009.

[4] South African Institute of Race Relations (NCP). Restitution of Land Rights Amendment Bill, 1-13, 2013.

[5] Metelerkamp, L., Land Reform in South Africa: Reflections on Indian Experience. Institute of Sustainability, 1-23, 2011.

[6] South African History Online. Timeline of Land Dispossession and Restitution in South Africa 1995-2013. http://www.sahistory.org.za.

[7] Paul, D., Analysis: Land Reform or Restitution, that is the question. Daily Maverick. http://www.dailymaverick.co.za/2011-05-04.

[8] Hall, R., The Impact of Land Restitution and Land Reform on Livelihoods. School of Government, University of Western Cape, 1-22, 2007.

[9] Brandon, E., Parliamentary Exhibitions: 'South Africa, our Land - The 1913 Land Act: One Hundred Years On'. Republic of South Africa, Pretoria, 1-11, 2013.

[10] Karuiki, S., Agrarian Reform, Rural Development and Governance in Africa: A Case of Eastern and Southern Africa. Centre for Policy Studies, 2009.

[11] Lancaster House Agreement. Southern Rhodesia Constitutional Conference. London, 1-51, 1979.

[12] Africa All Party Parliamentary Group. Land in Zimbabwe: Past Mistakes, Future Prospects. 1-52, 2009.

[13] Fourie, D.J. \& Schoeman, L., Local Government and Sustainable Post-Settlement Support for Restitution: in Search of Efficient Governance Objectives in Public Administration. Journal of Public Administration, 45 (1.1), 145-161, 2010.

[14] Sangonet. http://www.ngopulse.org/article/land-redistribution-case-landreform-south-africa.

[15] England, A., South Africa's Black Farmers Struggle with Land Reform. http://www.ft.com/intl/cms/s/0/efb94b78-5bf2-11e3-00144feabdc0.html. 
[16] White, M.J., Land Claims and Restitution in South Africa: The Valuation Perspective. $4^{\text {th }}$ Pacific Rim Real Estate Society Conference, Perth, 1-8, 1998.

[17] Stickler, M.M., Land Restitution in South Africa. World Resources Institution, 1-8, 2012.

[18] Weideman, M., Who Shaped South Africa's Land Reform Policy? Politikon, 31 (2), 219-238.

[19] Lahiff, E., Land Reform in South Africa: A Status Report. Programme for Land and Agrarian Studies, 1-42, 2008.

[20] Van der Merwe, P., \& Saayman, M., Game Farms as Sustainable Ecotourist Attractions'. Koedoe, 48 (2), 2005.

[21] Viljoen, J., \& Tlabela, K., Rural Tourism Development in South Africa. Human Science Research Council, Cape Town, 2007.

[22] Langholz, J.A., \& Kerley, G.I.H., Combining Conservation and Development on Private Lands: An Assessment of Ecotourism-Based Private Game Reserves in the Eastern Cape. Center for African Ecology, 56, 2006.

[23] Saayman, M., van der Merwe \& Rossouw, R., The Impact of Hunting for Biltong Purposes on the SA Economy. Acta Commercii, 1-11, 2011.

[24] Cloete, P.C., Taljaard, P.R., \& Grove, B., A Comparative Economic Case Study of Switching from Cattle Farming to Game Ranching in the Northern Cape Province. South African Journal of Wildlife Research, 37 (1), 71-78, 2007.

[25] Child, B.A., Musengezi, J., Parent, G.D., \& Child, G.f.T., The Economics and Institutional Economics of Wildlife on Private Land in Africa. Pastoralism Journal, 2 (18), 2012.

[26] Sebola, M.P., Ecotourism in South Africa: Potential, Opportunity and Politics. Journal of Public Administration, 43 (1), 59-71, 2008.

[27] Carruthers, J., "Wilding the Farm or Farming the Wild"? The Evolution of Scientific Game Ranching in South Africa from the 1960s to the Present. Transactions of Royal Society of South Africa, 63 (2), 159-181, 2008.

[28] Cousins, J.A., Sadler, J.P., \& Evans, J., Exploring the Role of Private Wildlife Ranching as a Conservation Tool in Soul Africa: Stakeholder Perspectives. Ecology and Society, 13 (2), 1-16.

[29] Smith, N., \& Wilson, S.L., Changing Land Use Trends in the Thicket Biome: Pastoralism to Game Farming. Territorial Ecology Research Unit, 38, 1-22, 2002.

[30] Manji, A., Land Reform in the Shadow of the State: the Implementation of New Land Laws in Sub-Saharan Africa. Oxfarm, Addis Ababa, 1-11, 2001.

[31] Spenceley, A., Tourism, local livelihoods, and the Private Sector in South Africa: Case Studies on Growing Role of the Private Sector in Natural Resources Management. Sustainable Livelihoods in Southern Africa. Research Report 8, 1-134, 2003. 
[32] Spenceley, A, 2004. Responsible Nature Based Tourism Planning in South Africa and the Commercialisation of the Kruger National Park, in D Dimitrios (ed), Ecotourism. Learning Thomson Learning, London.

[33] Aliber M., \& Maluleke T., The role of "black capital" in revitalizing land reform in Limpopo, South Africa. Law, Democracy and Development, 14: $1-3,2010$.

[34] Sebola, M.P., Community Prosperity through Local Economic Development: Maleboho Nature Reserve. Tshwane University of Technology, Pretoria, 1-2812007.

[35] Barry, M., Dysfunctional Communal Property Associations in South Africa: the Elandskloof Case. 1-23, 2009.

[36] Dikganga, J., \& Muchapondwa, E., The Effect of Land Restitution on Poverty Reduction Among the Khomani San "Bushmen". Economic Research Southern Africa. National Treasury, Pretoria. 1-21, 2013.

[37] Bennett, J.E., Institutions and Governance of Communal Rangelands in South Africa. African Journal of Range \& Forage Science, 30 (1), 77-83, 2013.

[38] McCusker, B., The Impact of Membership in Communal Property Association on Livelihoods in the Northern Province, South Africa. GeoJournal, 56, 113-122, 2002.

[39] Rolston, H. Feeding People Versus Saving Nature. In Light A \& Rolston $\mathrm{H}$ (eds). Environmental Ethics: An Analogy. Blackwell Publishing, Oxford, 2003. 